\title{
Endüstriyel Sistemlerde Mikrobiyolojik Korozyon ve Önlenmesi
}

\author{
Nihal Doğruöz ${ }^{*}$ \\ İstanbul Üniversitesi, Fen Fakültesi, Biyoloji Bölümü, İstanbul
}

\begin{abstract}
Özet
Mikrobiyolojik korozyon (MIC) mikroorganizmalar tarafından oluşturulan korozyon sürecidir. MIC organik ve inorganik asitler ile metallerin bozunmasına neden olur ve bu yüzden endüstriyel ve diğer sistemlerin yapı bütünlüğünü tehlikeye atarak dünya çapında önemli bir sorun yaratır. Metalik yapıların yüzeyinde meydana gelen kompleks biyolojik ve inorganik süreçlerin doğru bir şekilde anlaşılması MIC'un önlenmesi ve koruma için etkili uygulamalar gerçekleştirmek için gereklidir. Ayrıca bu durum onarım maliyetlerini en aza indirmek için uygun bir strateji geliştirmemize yardımcı olacaktır. Bu derleme endüstriyel sistemlerde kullanılan metal yüzeylerde biyofilm oluşumu, mikrobiyolojik korozyon ve buna neden olan mikroorganizmaların tanımlanması ve sistemlerdeki bu oluşumların engellenmesi için doğru stratejilerin nasıl belirlenebileceğine dair öneriler içermektedir.
\end{abstract}

Anahtar Kelimeler: Biyofilm, Mikrobiyolojik korozyon, Metal, Korozyonun önlenmesi

\section{Microbial Corrosion and Prevention in Industrial Systems}

\begin{abstract}
Microbial corrosion (MIC) is corrosion process enhanced by microorganism. MIC causes deterioration of metals by organic and inorganic acids and thus compromise the integrity of industrial and other systems structures, creating significant problems worldwide. A proper understanding of the complex biological and inorganic processes occurring at the surface of metallic structures is needed to carry out effective treatments for MIC prevention and protection. Besides this situation will help us develop an appropriate strategy to minimize the costs in repairs. This review contains biofilm formation on metal surface used in industrial systems, microbial corrosion and identification of microorganisms that cause it, and in the systems for the prevention of the formation with suggestions for how to determine the right strategy.
\end{abstract}

Keywords: Biofilm, Microbial corrosion, Metal, Prevention of corrosion

\footnotetext{
"e-mail: nihaldogruoz@gmail.com
} 


\section{Giriş}

Endüstriyel sistemlerde kullanılan su standartları, içme suyu standartlarından farklıdır. Bu sistemlerde kullanılan sular steril değildir. Sistem sularında bulunan mikroorganizma sayısı çok az olsa da bulundukları ortamlarda yüzeye tutunarak mikroorganizma topluluklarını (biyofilm) oluşturur ve mikrobiyolojik korozyona (MIC) neden olarak endüstriyel sistemlerde hijyenik problemlere ve büyük miktarlarda maddi kayıplara yol açarlar. Metallerde oluşan tüm korozyon zararının yaklaşık \% 20’sinin mikrobiyolojik kökenli olduğu ileri sürülmektedir. [1]. Endüstriyel sistemlerde biyofilm ve mikrobiyolojik korozyon oluşumunun engellenmesi için çeşitli uygulamalara (biyosit uygulaması, mekanik temizlik, kimyasal temizlik vb.) rağmen çoğunlukla kullanılan stratejiler yetersiz ya da hatalıdır.

Metal yüzeylerdeki (bakır, çeşitli alaşımlar, paslanmaz, galvanizli ve karbon çelik) mikrobiyolojik korozyon, mikroorganizmalar ve onların metabolik ürünleri olan enzimler, hücre dışı polimerik maddeler, organik ve inorganik asitler, $\mathrm{H}_{2} \mathrm{~S}$ ve amonyak gibi uçucu bileşiklerle ilişkilidir. Mikroorganizmaların metal yüzeyi ile kurduğu ilişki ve etkileşimi sonucu ortaya çıkan elektrokimyasal reaksiyonlar metalin çözünerek korozyona uğramasına sebep olur. [2-6]. Mikroorganizmalar, sadece metal yüzeylerin korozyonundan değil beton, ahşap ve plastik gibi yapıların da aşınmasından sorumludur [7,8]. Özellikle uçak endüstrisinde, petrol ve gaz endüstrisinde kullanılan boru hatlarında, kimya endüstrisinde kullanılan tanklarda, gıda endüstrisinde fermantasyon ünitelerinde, soğutma kulelerinde ve onların 1sı değiştiricilerinde, atık arıtım tesislerinde, ilaç ve kağıt endüstrisinde, lağım ana borularında ve enerji endüstrisindeki soğutma sistemlerinde çok büyük ekonomik kayıplara yol açarken güvenlik ve sağlığı da tehdit etmektedir [9,10]. Mikrobiyolojik korozyon, hasarın giderilmesi için sistemlerin durdurulması, depo, tank ve borularının delinmesiyle oluşan ürün kaybı ve mikroorganizmaların üretilen ürünleri karbon kaynağı olarak kullanıp ürün kalitesini düşürmesi gibi problemlere neden olmaktadır.

Korozyon kaynaklı ekonomik kayıplar ülkelerin Gayri Safi Milli Gelir'inin yaklaşık \% 3,5 - \% 5' i kadardır. Türkiye'de bu değerin \% 4,5 dolayında olduğu tahmin edilmektedir [11,12]. Amerika Birleşik Devletleri mikrobiyolojik korozyon hasarına yıllık olarak yaklaşık 2 milyar Dolar harcarken [13] İngiltere'de bu miktar yıllık 300-500 milyon Sterlin'dir [14].

$\mathrm{Bu}$ derleme genel olarak endüstriyel sistemlerde kullanılan metallerde oluşan biyofilm, mikrobiyolojik korozyon ve buna neden olan mikroorganizmaların tanımlanması ve sistemlerdeki bu oluşumların engellenmesi için doğru stratejilerin nasıl belirlenebileceğine dair öneriler içermektedir. Ayrıca sistemlerde oluşan mikrobiyolojik korozyonun araştırılması ve çözüm arayışı için biyolog, mühendis, kimyagerlerin içinde olduğu disiplinler arası çalışmaların gerekliliğini gözler önüne sermektedir.

\section{Biyofilm Oluşumu ve Hücre Dıșı Polimerik Maddeler (EPS)}

Biyofilm, suyla teması olan yüzeye ve birbirlerine tutunmuş, oluşturdukları organik polimerik matriks içine gömülü mikroorganizma topluluğudur [15]. Bakteriler bulundukları ortamda bir yüzeye tutunma eğilimindedirler. Bunun sonucu olarak da serbest halde bulunan bakterilerin ekosistemlerinin sadece \%1'ini veya daha azını oluşturması şaşırtıcı değildir [16].

Biyofilm oluşum basamakları şöyledir:

1- Suda bulunan organik maddeler yüzeye tutunurlar ve yüzeyin elektrik yüklerini değiştirirler. 
2- Serbest halde bulunan bakteriler, yüzeye tutunmuş başka mikroorganizmalar veya organik maddelerle geçici olarak ilişki kurar. Bakterilerin bir kısmı, yüzeye geri dönüşümlü olarak tutunurken diğer bir kısmı da besinleri kullanarak çoğalırlar.

3- Bu bakteriler hücre dişı polimerik maddeler (EPS) salgılayarak yüzeye geri dönüşümsüz olarak tutunurlar.

4- Yüzeye yeni mikroorganizmalar ve besinlerin eklenmesiyle mikrokoloniler oluşur. Mikrokoloniler, oksijen, besin maddeleri ve atık maddelerin taşınmasını sağlayan su kanallarını içeren daha büyük yapıları oluşturur. Bu kanallar aracılığı ile su, besin, enzim, metabolit ve oksijen tüm biyofilm katmanlarına taşınır.

5- Biyofilm olgunlaştıktan sonra, biyofilm tabakasından yeni biyofilm oluşumu için bakteriler ya da biyofilm parçaları kopar yüzeydeki başka bölgeye yeniden tutunur.

EPS, bakteriler tarafından üretilen, yapısında polisakkarit, üronik asit, şeker, protein, karboksilik asit, lipit, nükleik asit ve metal bağlama yeteneğinde olan asidik aminoasit gibi fonksiyonel grupları bulunduran biyofilmin temel elemanıdır [17,18]. EPS biyofilme dayanıklılık, esneklik vermenin dışında biyofilmi oluşturan bakterileri, biyolojik ve olumsuz fiziksel/kimyasal koşullara karşı da (besinsizlik, antimikrobiyal ajanlar, kuruluk, protozoonlar, pH, oksijen vb.) korurmaktadır [19,20]. Bu da sistemlerde oluşan biyofilmle kolayca baş edilememesine yol açmaktadır. EPS, metal bağlama kapasitesi özelliği ile metalin çözünmesini sağladığ i için metal korozyonunda direkt bir rol oynamaktadır [17] ve bu kapasite metal iyon tipine ve bakteri türüne bağlıdır [21].

\subsection{Biyofilmin Olușumunu Etkileyen Faktörler}

Biyofilm heterojenik bir yapıya sahiptir ve içeriği de çevresel koşullara ve varolan organizmalara bağlı olarak değişmektedir [22,23]. Oluşan tüm biyofilmler, etkileri altında oldukları çeşitli fiziksel ve kimyasal faktörlerden dolayı bileşimleri ve canlı çeşitliliği bakımından benzersizdir. Biyofilm oluşumunu etkileyen birbiri ile ilişkili faktörleri şöyle sıralayabiliriz:

1- Bakterilerin tutundukları yüzeyin özellikleri ve pürüzlülüğü

2- Yüzeyin temasta olduğu suyun sıcaklığı, pH'sı, oksijen miktarı, akış hızı ve dezenfektan miktarı

3- Besin maddesi sentezi, gen transferi ve hücre-hücre sinyali (quorum sensing)

\section{Korozyon}

Korozyon, bir oksidasyon ve redüksiyon reaksiyonlarının meydana gelmesi ile oluşur. Oksidasyon reaksiyonunda atom bir elektron kaybeder, redüksiyonda ise atom bir elektron kazanır. Genel olarak oksidasyon aşağıdaki denklemle ifade edilir [24];

$\mathrm{M}-\mathrm{e}^{-} \rightarrow \mathrm{M}^{+}$

Redüksiyon yolları ise (Roberge 2008);

$\mathrm{M}^{+}+\mathrm{e}^{-} \rightarrow \mathrm{M}$ (Bir metal katyon ile)

$2 \mathrm{H}^{+}+2 \mathrm{e}^{-} \rightarrow \mathrm{H}_{2}$ (Hidrojen gibi bir katyon ile)

$\mathrm{O}_{2}+4 \mathrm{H}^{+}+4 \mathrm{e}^{-} \rightarrow 2 \mathrm{H}_{2} \mathrm{O}$ (Oksijen varlığında su oluşturarak)

$\mathrm{O}_{2}+2 \mathrm{H}_{2} \mathrm{O}+4 \mathrm{e}^{-} \rightarrow 4 \mathrm{OH}^{-}$(Hidroksil iyonlarıyla) 
Korozyon, su içindeki aşındırıcı etkenlerin spesifik saldırıları, yüzeydeki yarıklar tarafından oluşturulan eşit dağılım göstermeyen oksijen konsantrasyonları ve farklı metallerin temasları sonucunda metal yüzeyi boyunca eşit oranda oluşabilir [25]. Korozyonda, suyun kimyası, sudaki katkı maddeleri, malzeme seçimi ve mikrobiyoloji çok önemli bir rol oynar [24].

\section{Mikrobiyolojik Korozyon}

Mikrobiyal aktiviteden dolayı metalin bozunmasına mikrobiyolojik korozyon ya da biyokorozyon denir. Mikrobiyolojik korozyon, malzeme bilimi, kimya, mikrobiyoloji ve biyokimya alanlarını kucaklayan disiplinler arası bir konudur. Metaller üzerindeki ilk MIC raporu 1891 y1lında Garrett tarafından yayınlanmıştır [26]. Garrett, kaplı kabloların korozyonuna, biyojenik amonyak, nitrit ve nitratın neden olduğunu öne sürmüştür. Von Wolzogen Kühr ve Van der Vlugt [27] tarafından, anaerobik koşullar altında sülfat indirgeyen bakterilerin metal yüzeyden adsorplanmış hidrojen alarak metallerin korozyonunda doğrudan rol oynadığını gösteren ilk çalışma sunulmuştur.

Mikrobiyolojik korozyona neden olan mekanizmalar çok çeşitlidir. Mikroorganizmalar hem metabolizmaları aracıllı̆̆ ile ürettikleri ürünlerle, hem de direkt olarak bulundukları yüzeylerdeki metalleri enerji elde etmek için kullanarak korozyonu hızlandırabilir [28].

MIC oluşum zincirini kısaca şöyle ifade edebiliriz [29].

1- Mikroorganizmaların fiziksel varlığı ve metabolik aktiviteleri, yüzeylerin elektrokimyasal özelliklerini değişikliğe uğratır.

2- Mikroorganizmalar çoğalır ve koloni oluştururlar. Koloniler tüm yüzeyi kaplamaz. Yüzeyin koloni bulunmayan alanı ile koloni olan alanının oksijen miktarlarında farklılık oluşur. Bunlara farklı konsantrasyon hücreleri denir ve korozyon oluşumunda etkindir.

3- Ayrıca bir koloninin altında anod oluşurken hemen yanındaki alan katod haline gelmektedir. Metal yüzeyler üzerinde oluşan bu tür farkl1l1klar elektrik potansiyelleri arasında farkl1lığa sebep olur ve tüm bu farklılıklar MIC oluşumuna neden olurlar.

Korozyon ürünlerinin yüzeylerde birikimi sonucu sistemin verimliliği azalır. Bununla beraber korozyon, yüzeylerde hasara neden olarak depo, boru ya da sistemlerin yeniden kullanılmasını imkânsız hale getirerek kayıplara yol açar.

Korozyon görüntüleme yöntemleri içinde en sık kullanılan taramalı elektron mikroskobisidir (SEM). Enerji Yayıcı X-ışını spektroskopisi (EDS) ile SEM birlikte kullanılarak korozyon ürünlerinin elemental kompozisyonu belirlenebilir. Böylece hem metal yüzey morfolojilerinin hem de element analizinin eş zamanlı yapılması sağlanır. Diğer yöntem X-Işını Difraksiyon (XRD) spektroskopisidir. XRD ile korozyon ürünlerindeki bileşikler belirlenebilir.

\section{Korozyonda Önemli Rolleri Olan Mikroorganizmalar}

\subsection{Sülfat indirgeyici bakteriler (SRB)}

Sülfat indirgeyen bakteriler, mikrobiyolojik korozyona neden olan en önemli mikroorganizmalar olarak bilinir. SRB, organik bileşikleri ya da $\mathrm{H}_{2}$ 'i elektron vericisi olarak kullanarak, kükürt ve sülfatı indirgeyip $\mathrm{H}_{2} \mathrm{~S}$ üreten ve doğada çok yaygın olan anaerobik bir gruptur. Ancak SRB'in bazı türlerinin oksijene tolerans gösterdiği belirlenmiştir. SRB oksijensiz hale gelmiş sucul ve karasal çevrelerden 
yaygın olarak izole edilirler [30] ve doğal ve endüstriyel sistemlere ciddi zararlar vererek önemli ekonomik kayıplara neden olurlar. SRB tarafından meydana gelen korozyonun belirlenmesine yüzeyde, siyah kokulu FeS'ün birikimi yardımcı olur. Sülfat indirgeyen bakterilerin korozyona etki mekanizması von Wolzogen Kuhr ve van der Vlugt [27] tarafindan ortaya konan katodik depolarizasyon teorisi ile şöyle açıklanmıştır.

$$
\begin{aligned}
& 4 \mathrm{Fe} \rightarrow 4 \mathrm{Fe}^{+2}+8 \mathrm{e}^{-} \quad \text { (anodik reaksiyon) } \\
& 8 \mathrm{H}_{2} \mathrm{O} \rightarrow 8 \mathrm{H}^{+}+2 \mathrm{OH}^{-} \text {(suyun ayrışması) } \\
& 8 \mathrm{H}^{+}+8 \mathrm{e}^{-} \rightarrow 4 \mathrm{H}_{2} \quad \text { (katodik reaksiyon) } \\
& \mathrm{SO}_{4}^{-2}+4 \mathrm{H}_{2} \rightarrow \mathrm{S}^{-2}+4 \mathrm{H}_{2} \mathrm{O} \quad \text { (bakteriyal tüketim) } \\
& \mathrm{Fe}^{+2}+\mathrm{S}^{-2} \rightarrow \mathrm{FeS} \text { (korozyon ürünü) } \\
& 3 \mathrm{Fe}^{+2}+6 \mathrm{OH}^{-} \rightarrow 3 \mathrm{Fe}\left(\mathrm{OH}_{2}\right)(\text { korozyon ürünü) } \\
& 4 \mathrm{Fe}+\mathrm{SO}_{4}^{-2}+4 \mathrm{H}_{2} \mathrm{O} \rightarrow 3 \mathrm{Fe}(\mathrm{OH})_{2}+\mathrm{FeS}+2 \mathrm{OH}^{-} \text {(toplam reaksiyon) }
\end{aligned}
$$

Tüm bu basamaklar, hidrojenin demir yüzeydeki katodik alandan bakteri hidrojenazları ile uzaklaştırılmasıdır, bu işlemin beraberinde sülfat sülfite indirgenir.

\subsection{Kükürt okside eden bakteriler (SOB)}

MIC' da etkin olan diğer bakteriler kükürt okside edenlerdir. Metal yüzeylerde de elemental kükürt, tiyosülfat, metal sülfitler, $\mathrm{H}_{2} \mathrm{~S}$ ve tetratiyonatları okside ederek sülfürik asit oluştururlar. Yüzeyde korozyon ürünü olarak sarı renkte birikimlerin oluşması yüzeyin SOB tarafından korozyona uğratıldığını düşündürür. Nötral ve asidik pH ortamlarında yaşayanlar olmak üzere iki gruba ayrılırlar. Thiobacillus, Beggiatoa ve Sulfolobus en iyi bilinen aerobik kükürt okside eden bakteri cinsleridir. Asidofilik kükürt okside edenlerin bazıları örneğin Thiobacillus ferrooxidans türü demiri de oksitleyerek korozyonu daha da hızlandırabilmektedir. Thiobacillus cinsi bakterilerin 5 türünün korozyonda önemli bir rol oynadıkları bulunmuştur. Bu türler T. thioparus, T. novelis, T. neapolitanus, T. intermedius (nötrofilik kükürt okside eden) ve T. thiooxidans (asidofilik kükürt okside eden) bakterilerdir [31].

$$
\begin{aligned}
& \mathrm{H}_{2} \mathrm{~S}+2 \mathrm{O}_{2} \rightarrow \mathrm{SO}_{4}^{-2}+2 \mathrm{H}^{+} \\
& \mathrm{S}+2 \mathrm{H}_{2} \mathrm{O}+3 \mathrm{O}_{2} \rightarrow 2 \mathrm{SO}_{4}^{-2}+4 \mathrm{H}^{+} \\
& 4 \mathrm{~S}_{2} \mathrm{O}_{3}^{-2}+2 \mathrm{H}_{2} \mathrm{O}+\mathrm{O}_{2} \rightarrow 2 \mathrm{~S}_{4} \mathrm{O}_{6}^{-2}+4 \mathrm{OH}^{-} \\
& 2 \mathrm{~S}_{4} \mathrm{O}_{6}{ }^{-2}+6 \mathrm{H}_{2} \mathrm{O}+7 \mathrm{O}_{2} \rightarrow 8 \mathrm{SO}_{4}^{-2}+12 \mathrm{H}^{+}
\end{aligned}
$$

\subsection{Asit üreten bakteriler}

Kükürt okside eden bakteriler dışındaki asit üreten diğer bakteriler, organik maddelerin fermantasyonu esnasında organik asitleri oluşturan heterotrofik bakterilerdir. Bu bakteriler metabolizmaları sonucu korozyon oluşumunda etkili olan asetik, formik ve laktik asit üretirler [32-34].

\subsection{Demir ve mangan indirgeyen bakteriler}

Pseudomonas ve Shewanella cinsi bakteriler mangan ve/veya demir oksiti indirgeyerek korozyonu hızlandırmaktadır. Mikroorganizmalar, metal yüzey üzerindeki korozyona dirençli oksit filmlerin çözünmesine yol açarak demir ve demir alaşımlarında korozyonun oluşmasına neden olmaktadır. Demir indirgeyen bakteriler düşük $\mathrm{pH}$ değerleri haricinde çözünmez formda olan $\mathrm{Fe}^{+3}$ ' ü $\mathrm{Fe}^{+2,}$ ye indirgemektedirler. Bu reaksiyonla metal yüzey üzerindeki koruyucu $\mathrm{Fe}_{2} \mathrm{O}_{3}$ filminin çözünür ve korozyon oluşumu başlar. Demir indirgeyen bakterilerin korozyon ürünleri koyu yeşilimsi renktedir $[35,36]$. 
Gallionella, Leptothrix, Crenothrix, Sphaerotilus cinsi bakteriler demir ve mangan gibi metalleri oksitleyerek enerji elde ederler. Demir oksitleyici bakteriler (Gallionella, Leptothrix) bulunduğu sıvıdaki ya da yüzeye tutunmuş halde bulunan $\mathrm{Fe}^{+2}$ yi çözünmeyen $\mathrm{Fe}^{+3}$ ' $\mathrm{e}$ oksitlerler. Demir okside eden bakteriler yüzeylerde kırmızı-kahverengi renkte korozyon ürünü oluştururlar. Bu bakteri cinsleri aynı zamanda mangan iyonların da okside ederek mangandioksitin birikimine neden olur [37]. Demir ve mangan oksitleyen bakterilerin oluşturduğu tüberküller, çeşitli metallerin yüzeylerinde oluşan ince pasif oksit filmin kararlılığını etkilemektedir. Bunun yanında bu bakteriler, oksijen konsantrasyon hücreleri oluşturarak korozyon reaksiyonlarını hızlandırmaktadır [33,34,38].

\subsection{Metan üreten arkeler}

Metan üreten arkeler zorunlu anaeroblardır. Metanojenler eşsiz metabolizmaları ile anaerobik koşullarda $\mathrm{H}_{2}$ 'i elektron vericisi, $\mathrm{CO}_{2}$, piruvat, asetat, metillenmiş substratları ise elektron alıcısı olarak kullanarak metanı $\left(\mathrm{CH}_{4}\right)$ üretirler. Metanojenlerin çok sayıdaki türü sadece elektron kaynağı olarak demir ve diğer metalleri kullanırlar. Metanojenlerin, demir ve çeliği korozyona uğrattıkları gösterilmiştir [39].

\subsection{Fotosentetik bakteriler ve Algler}

Fotosentetik bakteriler ve algler ışığı kullanarak fotosentez yaparak oksijeni üretirler. Böylelikle metal yüzeylerde oluşan biyofilmin bir bölgesinde yüksek oksijen diğer bir bölgesinde düşük oksijen konsantrasyonuna sahip, farklı konsantrasyon hücrelerini oluştururlar. Aerobik koşullar altında solunum yapan bakteri topluluğunun altındaki alan anodik, çevresindeki alan katodiktir. Olgun biyofilm, katodik alana oksijen difüzyonunu, anodik alana klor gibi agresif anyonların difüzyonunu, metabolit ve korozyon ürünlerinin biyofilm dışına difüzyonunu engeller. Sonuçta biyofilm içinde oksijen tükenen bölgelerde anaerobik alan oluşur. Bu durum katodik mekanizma değişimi meydana geldiğini işaret eder. $\mathrm{Bu}$ oluşumların sonucunda korozyon hızlanır [13, 40-42].

\subsection{Mantarlar}

Mantarlar metabolizmaları sonucunda organik asitleri üretir ve ortamın $\mathrm{pH}$ değerini düşürürler bundan dolayı da mikrobiyolojik korozyonun oluşumunda rol oynarlar. Mantarlar tarafindan üretilen organik asitlerin boyalı karbon çelikte oyuklanma korozyonuna neden olduğu gösterilmiştir [7, 43].

\subsection{Amonyak üreten bakteriler}

Nitrat indirgeyen bakteriler, $\mathrm{NH}_{4}{ }^{+}$formunu, nitrat1, nitriti indirgeyerek, aminoasit ya da üreyi parçalayarak amonyak oluştururlar. Pope ve diğ. [44] amonyak üreten bakterilerin korozyona neden olduklarını deneysel olarak göstermişlerdir.

\section{Endüstriyel sistemlerde sıklıkla kullanılan metal ve alaşımlarının mikrobiyolojik korozyonu}

\subsection{Bakır ve alaşımları}

Bakır, 1sı ve elektriği yüksek oranda iletebilen ve çok iyi korozyon direncine sahip soy bir metaldir [45]. Bakır (II) iyonlarının birçok mikroorganizma için toksik olduğu bilinmesine rağmen, bakır korozyonuna neden olan mikroorganizmaların varlığını gösteren çalışmalar da literatüre geçmiştir. Bu çalışmalar bakırın korozyonuna neden olan mikroorganizmaların bakırın toksik etkisine dirençli olduklarını ortaya koymaktadır. Rajasekar ve Ting [46] tarafından yapılan çalışmada, soğutma kulesinden 
izole edilen Massilia timonae'nin bakır yüzeylerde korozyona neden olduklarını gösterilmiştir. Diğer bir çalışmada ise Pseudomonas aeruginosa' nın nikel-bakır alaşımının korozyonunu hızlandırdığı belirlenmiştir [47]. Bakırın mikrobiyolojik korozyonunda en önemli rolü EPS oynar. EPS ya içeriğinde bulunan proteinlerle ya da asidik karbohidratları ile bakır bağlayarak mikrobiyojik etkili korozyona neden olurlar [48]. Bakır korozyonunun ilk ürünü olan kuprit $\left(\mathrm{Cu}_{2} \mathrm{O}\right)$, bakırın su molekülleri ya da $\mathrm{O}_{2}$ 'le çözünmesi ile oluşan direkt reaksiyon ürünüdür. Bakır yüzeylerde oluşan bakır oksit filmin farklı $\mathrm{pH}$ değerlerinde farklı şekillerde etkilenirler. pH 8'de bakır yüzeydeki oksit film ince ve sıkı iken pH 6.8'de kalın ve porlu yapı göstererek MIC oluşumunu hızlandırmaktadır [10].

\subsection{Paslanmaz çelik}

Paslanmaz çelik elektrokimyasal korozyona dayanıklı pasif ince filmler oluşturabildiği için endüstride çok geniş kullanım alanına sahiptirler. Paslanmaz çeliklerde krom atomları (en az \%12) ile oksijen atomlarının reaksiyonu sonucu krom oksit filmi oluşur. Çeşitli nedenlerden dolayı bu pasif filmin kalkması sonucu paslanmaz çeliğin korozyonu gelişir. Okside olmuş yüzeyde metal biriktiren bakteriler tarafindan organik ve inorganik birikimlerin oluşumu bu filmin stabilitesini tehlikeye atar. Metal yüzeylerde metal biriktiren bakterilerin yoğun olması katodik olarak reaktif demirin birikimi ile korozyonun ilerlemesine, o bölgedeki bakteriyel solunumdan dolayı oksijenin lokal olarak tüketimine ve korozif olan mangan oksitlerin oluşumuna neden olabilir [4,37,42]. Rajasekar ve Ting [49] Bacillus megaterium ve Pseudomonas sp.'in içinde bulundukları paslanmaz çelik üzerindeki korozyon etkisinin içinde bulundukları ortamın inorganik ya da organik olmasına göre değiştiğini bildirmişlerdir. Bacillus megaterium ve Pseudomonas sp. inorganik besiyerinde iken paslanmaz çeliğin korozyonu azalırken, organik besiyerinde korozyon hızlanmaktadır. Bu çalışmalar çalışmadaki herbir parametrenin önemli olduğunu ve parametreler değiştiğinde farklı sonuçların ortaya çıkabileceğine işaret etmektedir. Korozyonun engellenmesi için stratejiler belirlenirken, disiplinlerarası ön çalışmaların yapılması gerektiği ortadadır.

\subsection{Alüminyum ve alaşımları}

Alüminyum ve alaşımlarının korozyon direnci alüminyum oksit pasif filminden ileri gelir. Alüminyum ve alaşımlarındaki doğal filme klor, brom, flor iyonları tarafından saldırılabilir. Ancak alüminyum ve alaşımları lokal korozyona hassastır ve özellikle mikrobiyolojik korozyon ile hasar görür. Alüminyumun mikrobiyolojik korozyonu ile ilgili çok sayıda çalışma vardır. Alüminyum ve alaşımlarının korozyonunda tanımlanan iki mekanizma vardır. Bunlardan biri bakteri ve mantarlar tarafindan üretilen organik asitler diğeri ise farklı hava hücrelerinin oluşumudur [50]. Pseudomonas aeruginosa, Aerobacter aerogenes, Desulfovibrio ve Cladosporium türlerinin uçak yakıt tanklarında oluşturdukları metabolik ürünler, farklı konsantrasyon hücreleri korozyona sebep olurlar. Ayrıca alüminyum yüzeylerin korozyondan korunması için sıklıkla kullanılan nitrat temelli korozyon inhibitörlerinin besin olarak kullanmaları sonucunda da korozyon oluşabilir/hızlanabilir [44].

\subsection{Titanyum}

Titanyum ve alaşımları yüksek ısıya dayanması, iyi bir mekanik yapıya sahip olması, hafifliği ve yüksek korozyon direncine sahip olması kullanım alanlarını arttırmaktadır. Fiyatının yüksek olması dezavantajıdır. Diğer metallerin kullanılamayacağı yerler için tercih edilmektedir [51]. 2005 yılına kadar 
titanyumun mikrobiyolojik korozyonuna dair bir veri yokken, Rao ve diğ. [52] titanyumun SRB tarafından korozyona uğradığı rapor etmiştir.

\section{Endüstriyel sistemlerde mikrobiyolojik korozyonun önlenmesi}

Endüstriyel su sistemlerinde biyofilm oluşumu, mikrobiyolojik korozyon, korozyon ürünlerinin ya da kalsiyum, magnezyum gibi minerallerin su içindeki konsantrasyonlarına, suyun fiziksel ve kimyasal parametrelerine bağlı olarak çökelip tortu oluşturması gibi çeşitli problemler görülür [22,53,54].

Endüstriyel sistemlerde biyofilm ve mikrobiyolojik korozyonun önlenmesi ve kontrolü için çeşitli yöntemler kullanılmaktadır. Ancak sistemde bir kere biyofilm oluştuktan sonra sistemin biyofilmden arındırılması çok kolay değildir.

İlk sırada gelen yöntem sistemlerin fiziksel olarak temizlenmesidir. Mekanik temizlik, biyofilm ve mikrobiyolojik korozyonun önlenmesinde çok etkilidir [55]. Ancak her sistem mekanik temizlik için uygun değildir. Sistemlerde bulunan ölü noktalara ulaşmak imkânsızdır. Sistemler dizayn edilirken bunlar göz önünde bulundurulmalıdır.

Mekanik temizliğin hemen ardından uygun kimyasal temizlik yapılmalıdır. Kimyasal temizlikte, mineral ve organik asitler korozyon inhibitörleri ile beraber kullanılır ve metalden çözünmüş iyonların yüzeyden uzaklaştırılmasını sağlar [55]. Ancak burada da çok dikkat edilmelidir. Kullanılan asitler metallerin korozyonuna neden olabileceğinden sisteme korozyon inhibitörleri ile verilmelidir. Ancak korozyon inhibitörleri de dikkatle seçilmelidir.

Korozyondan korunmanın en önemli yollarından biri de korozyona dayanıklı malzemenin seçimidir. Malzeme seçerken kullanılacak sistem ve metalin bulunacağı ortam göz önüne alınmalıdır. Metalin kullanılacağı ortamın kimyasal özelliklerine göre korozyona dirençli metal ve alaşımlar seçilmelidir. Seçilen metalin veya alaşımın mikrobiyolojik korozyona da dirençli olması göz önünde bulundurulmalıdır. Kullanılacak malzemenin yüzeyi epoksi boya, metal kaplama ya da plastik gibi koruyucu kaplamalar uygulanarak da korozyondan korunma sağlanabilir. Ancak burada da dikkat edilmesi gereken husus kaplama maddesi parçalandığında ortama korozif bileşiklerin salınmaması ve bu kaplama maddesinin bakteriler tarafından besin maddesi olarak kullanılmamasıdır [22,55]. Sistemlerde biyofilm oluşumu ve mikrobiyolojik korozyonun önlenmesi için en yaygın uygulanan yöntem mikroorganizmaları öldüren ya da üremelerini durduran kimyasal bileşikler yani biyositlerin kullanılmasıdır. Biyositlerin etkin olduğu pH değerlerinin bilinmesi uygulamanın başarılı olması için gereklidir. Her sistemde oluşan biyofilm farklı ve eşsiz olduğundan kullanılacak biyositin seçimi zordur. Dolayısı ile kullanılan biyosit bir sistemde etkili olurken diğerinde etkili olmayabilir. O nedenle sistemlerde biyosit kullanılmadan önce sistem biyofilmlerine karşı laboratuvarlarda deneysel olarak etkinlikleri test edilmeli en uygun biyosit ve dozu seçilmeli ve ardından sisteme uygulanmalıdır [56]. Ancak biyosit kullanımı çoğunlukla sistem bakımlarını yapan personel tarafından bilinçsizce yapılmaktadır. Biyositin sistemlere belli dozlarda verilmesi gerekirken ölçüsüz olarak boca edilmektedir. $\mathrm{Bu}$ uygulama, sistemde kullanılan suyun kimyasal özelliklerini değiştirerek sistemin korozyona uğramasını hızlandırmaktadır.

Biyositin korozif etkisini azaltmak için biyosite uygun, yüzeylerde koruyucu tabaka oluşturan korozyon inhibitörleri kullanılmalıdır [57,58]. Korozyon inhibitörleri seçilirken çok dikkatli olunmalıdır. 
Fosfat ve nitrat temelli korozyon inhibitörleri mikroorganizmalar tarafindan besin maddesi olarak kullanılabilir. Nitekim yapılan bir çalışmada fosfat temelli korozyon inhbitörlerinin mikroorganizmalar tarafından besin olarak kullanıldığı ve sistemdeki bakteri sayısını arttırdığı gösterilmiştir [59]. Bu uygulama sonucu bakteri sayısı artarak biyofilm oluşumu desteklenmiş olur. Seçilen biyositin çevreye zarar vermemesi gerekir. Seçimleri yaparken ya da yeni bir biyosit üretiminde çevre dostu olması önemlidir. Bu yanlışların yapılmaması için malzeme, biyosit, korozyon inhibitörü seçimi ve bu faktörlerin deneylsel olarak bir arada değerlendirilmesi oldukça önemlidir. Bu seçimlerin doğru yapılabilmesi için mühendisler ve mikrobiyologlar ortak çalışmalıdır. Sistemlerden sorumlu olan personel eğitilmelidir.

Diğer bir yöntem de katodik korumadır. Korozyonu önlemek için sistemde kullanılan metalin dışında onunla temas edecek başka bir metalin yerleştirilerek yüzeyde koruma tabakası oluşturulmaktadır. Ancak mikroorganizmaların metabolizmaları sonucu yüzeyde oluşan bu tabakanın etkisini yitirdiği de bilinmektedir [60].

Bu yöntemler dışında bazı biyofilmler kullanılarak korozyonun önlenmesi üzerine çalışmalar da yapılmaktadır [61,62]. Bu koruma biyofilmlerin metal çözünmesini engellemesi ya da biofilmdeki aerobik mikroorganizmaların oksijeni kullanarak metal yüzeydeki oksijen konsantrasyonunu düşürmesiyle ortaya çıkabilir. Ayrıca Bacillus gibi çeşitli maddeler üreterek diğer mikroorganizmaların çoğalmasını engelleyen bakterilerin biyofilm oluşumunu etkileyerek metal yüzeylerdeki korozyon hızını azalttığı bilinmektedir [63]. Tek tür mikroorganizmalarla laboratuvar şartlarında yapılan deney sonuçlarına göre kullanılan metalin korozyonu engellense de doğal sistemler karışık mikroorganizmalar topluluklarından oluşur. Dolayısı ile gerçek sistemlerde sonuçlar farklı olabilir. Bu tarz çalışmaların karışık kültürlerin bulunduğu sistemlerde gerçekleştirilmesi pratikte kullanımı açısından daha anlamlı olacaktır.

Endüstriyel sistemlerde biyofilm oluşumunu ve korozyonu önlemek için çok çeşitli yöntemler vardır. Bu yöntemlerin birbiri ile ilişkisi göz ardı edilmemelidir. Sadece bir veya ikisini uygulamak sistemlerde biyofilm ve korozyon oluşumunu engellemek için yeterli olmamaktadır. Tüm koşullar göz önüne alınarak, seçimlerin en doğru şekilde yapılması için gerekli testlerin ve ön denemelerin yapılmasına özen gösterilmeli, test sonuçlarına göre malzeme, biyosit ve korozyon inhibitör seçimi yapılmalıdır. Bunun için disiplinler arası bir ekip kurulmalıdır. Personel eğitilmelidir.

\section{Kaynaklar}

[1] Javaherdashti, R., "Microbiologically influenced corrosion: an engineering insight Handbook" Springer Ltd, Verlag London, 2008

[2] Beale D. J., Morrison P. D., Key C., Palombo E. A., “ Metabolic profiling of biofilm bacteria known to cause microbial influenced corrosion” Water Science \& Technology, 69, 1-8, 2014

[3] Xu F., Lin C., Wei R., Zheng J., Zhang J., Wang L., Sun Z., "The Influence of the Aerobic Bacterium on the Electrochemical Corrosion Behavior of B10 Alloys" International Journal of Electrochemical Science, 8, 8700-8707, 2013

[4] Wesley S. B., Maurya D. P., Goyal H. S., Negi, S., "Experimental investigation of microbiologically influenced corrosion of selected steels in sugarcane juice environment" World

Journal of Microbiology and Biotechnology, 29, 2353-2357, 2013 
[5] Minnoş B., Ilhan-Sungur E., Çotuk A., Güngör N. D., Cansever N., “ The corrosion behaviour of galvanized steel in cooling tower water containing a biocide and a corrosion inhibitör" Biofouling, 29, 223-235, 2013

[6] Ovri, J., Okeahialam, S., Onyemaobi, O.” Microbial corrosion of mild and medium carbon steels” Journal of Engineering Science and Technology, 8, 639-653, 2013

[7] Görs S., Schumann R., Häubner N., Karsten U., "Fungal and algal biomass in biofilms on artificial surfaces quantified by ergosterol and chlorophyll a as biomarkers" International Biodeterioration and Biodegradation, 60, 50-59, 2007

[8] Javaherdashti, R., “A Brief Review of general Patterns of MIC of Carbon Steel and Biodegration of Concrete", IUFS Journal of Biology, 68, 65 -73, 2009

[9] Beech I. B., Gaylarde C.C., "Recent advances in the study of biocorrosion - an overview" Revista de Microbiologia, 30, 177-190, 1999

[10] Little B.J., Lee J.S., "Microbiologically influenced corrosion” Wiley-Interscience A John Wiley \& Sons,Inc., Publication, 978-0-471-77276-7, Canada, 2007

[11] Çakır A.F., VII. Türk Ekonomisinde Korozyon Kaybının Boyutları ve İrdelemeler, Uluslararası Metalurji ve Malzeme Kongresi Bildiriler Kitabı, Ankara, 1985, 4-8 May1s cilt II, 1347,1993

[12] Çakır A.F., "Progress in the Understanding and Prevention of Corrosion, The Priority of Corrosion and Protetion in the Turkish Economy" Edited by Costa J.M., Mercer, A.D., The Institute of Materials, Vol. 11, 671, 1993.

[13] Thierry D., Sand, W., "Microbially influenced corrosion” Edited by Marcus P., Oudar J., Corrosion mechanism in theory and practice: second edition, Marcel Dekker, 563-605, New York, 2002

[14] Hamilton W.A., "Sulphate reducing bacteria and anaerobic corrosion" Annual Review of Microbiology, 39, 195-217, 1985

[15] Marshall K.C., "Colonization, Adhesion, and Biofilms” Edited by Hurst C.J., Knudsen G.R., Mclnerney M.J., Stetzenbach L.D., Walter M.V., Manual of Environmental Microbiology, ASM, Washington, D.C. 358-365, 1997

[16] Costerton J.W., Nickel J.C., Ladd T.I., "Bacteria in nature" Plenum Publishing Corp., 030643173-4, New York, 1986

[17] Qin-qin T., Zhi-rong L., Ying D., Xin-xing Z., "Biosorption properties of extracellular polymeric substances towards Zn (II) and Cu (II)" Desalination and Water Treatment, 45, 40-47, 2012

[18] Wang Z., Hessler C.M., Xue,Z., Seo Y., "The role of extracellular polymeric substances on the sorption of natural organic matter" Water Research, 46, 1052-1060, 2012

[19] Nwodo U., Ezeikel G., Okoh A., "Bacterial Exopolysaccharides: Functionality and Prospects" International Journal of Molecular Sciences, 13, 14002-14015, 2012

[20] Lehman A., Long S., “ Exopolysaccharides from Sinorhizobiummeliloti can protect against H2O2-dependent damage" Journal of Biotechnology, doi: 10.1128/JB.00681-13 JB, 00681-13, 2013 
[21] Beech, I.B., Sunner, J.A., Hiraoka, K., "Microbe- surface interactions in biofouling and biocorrosion processes” International microbiology, 8, 157-168, 2005

[22] Videla H.A., "Manual of biocorrosion" Microbial diversityin biofilms from corroding heating systems, CRC Press, 0873717260, 2005, UK,1996

[23] Flemming H. C., Wingender J., "The biofilm matrix" Nature Reviews Microbiology, 8, 623633,2010

[24] Roberge P.R., "Corrosion engineering principles and practice" McGraw-Hill Professional Publishing, United States of America, 2008

[25] Cicek V., Al-Numan B., "Corrosion chemistry" John Wiley \& Sons, United States of America, 2011

[26] Garret J.H., “The Action of Water on Lead” H.K. Lewis, London, England, 1891

[27] Wolzogen Kuhr C. V., van der Vlugt I. S., "The graphitization of cat iron as an electrochemical process in anaerobic solid" Water, 18, 147-165, 1934

[28] Critchley M., Javaherdashti R., "Materials, microorganisms and microbial corrosion- Areview" Corrosion and Materials, 30, 8-11, 2005

[29] Kjellerup, B.V., Thomsen, T.R., Nielsen, J.L., Olesen, B.H., Frolund, B., Nielsen, P.H., "Microbial diversity in biofilms from corroding heating systems" Biofouling, 21, 19- 29, 2005

[30] Postgate J.R., "The sulphate reducing bacteria" 2nd Cambridge University Press, 0521257913, Cambridge, 1984

[31] Mori T., Nonaka T., Tazaki K., Koga M., Hikosaka Y., Noda S., "Interactions of nutrients, moisture and $\mathrm{pH}$ on microbial corrosion of concrete sewer pipes" Water Research, 26, 2937,1992

[32] Sand W., "Microbial mechanisms of deterioration of inorganic substrates- a general mechanistic overview" International Biodeterioration and Biodegradation, 40, 183-190,1997

[33] Little, B.J., Wagner, P., Hart, K., Ray, R., Lavoie, D., Nealson, K., Aguilar, C., "The role of metal-reducing bacteria in microbiologically influenced corrosion” Proc. NACE Corrosion 97, NACE International, Houston, 215, 1997

[34] Roberts D.J., Nica D., Zuo G., Davis J.L., "Quantifying microbially induced deterioration of concrete: initial studies" International Biodeterioration and Biodegradation, 49, 227-234, 2002

[35] Obuekwe C.O., Westlake, D.W.S., Plambeck, J.A., Cook, F.D., "Corrosion of mild steel in cultures of ferric iron reducing bacterium isolated from crude oil I. Polarization characteristics" Corrosion, 37, 461-467, 1981

[36] Myers C., Nealson K.H., "Bacterial manganese reduction and growth with manganese oxide as the sole electron acceptor" Science, 240, 1319-1321, 1988

[37] Ghiorse W.C., "Biology of Iron-and Manganese-Depositing Bacteria" Annual Review of Microbiology, 38, 515-550, 1984

[38] Gounot A.M., "Microbial oxidation and reduction of manganese: Consequences in groundwater and applications” FEMS Microbiology Reviews, 14, 339-350, 1994

[39] Boopathy R., Daniels L., " Effect of pH on anaerobic mild steel corrosion by methanogenic bacteria” Applied and Environmental Microbiology, 57, 2104-2108, 1991 
[40] Hadley, R.F., "Corrosion by micro-organisms in aqueous and soil environments" Edited by Uhlig H.H., Corrosion handbook, John Wiley \& Sons, 0471895628, USA, 466-470,1948

[41] Ford T., Mitchell R., "The ecology of microbial corrosion. In Advances in microbial ecology" Springer, US, 231-262, 1990

[42] Little B.J., Wagner P.A., Mansfeld F., “An overview of microbiologically influenced corrosion” Electrochimica Acta, 37, 1-17, 1992

[43] Little B., Ray R., Hart K., Wagner P., "Fungal-induced corrosion of wire rope" Materials Performance, 34, 55-58, 1995

[44] Pope D.H., Duquette D.J., Johannes A.H., Wayner P.C., "Microbiologically influenced corrosion of industrial alloys" Materials Performance, 23, 14-18, 1984

[45] Wagner P., Little B., "Impact of Alloying on Microbiologically Influenced Corrosion. A Review" Materials Performance, 32, 65-68, 1993

[46] Rajasekar A., Ting Y.P., "Characterization of Corrosive Bacterial Consortia Isolated from Water in a Cooling Tower” International Scholarly Research Notices, 2014

[47] San N. O., Nazır H., Dönmez G., "Microbially influenced corrosion and inhibition of nickel-zinc and nickel-copper coatings by Pseudomonas aeruginosa” Corrosion Science, 79, 177-183, 2014

[48] Wagner D., Chamberlain, A.H.L., "Microbiologically influenced copper corrosion in potable water with emphasis on practical relevance" Biodegradation, 8, 177-187, 1997

[49] Rajasekar A., Ting Y.P., "Role of inorganic and organic medium in the corrosion behavior of Bacillus megaterium and Pseudomonas sp. in stainless steel SS 304,” Industrial and Engineering Chemistry Research, 50, 12534-12541, 2011

[50] Dayal H. M., Tewari K. C., Mehta K., Shekhar C., "Underground Cordon by MicroorganismsPart-III Role of Soil Inhabiting Actinomycetes” Defence Science Journal, 39, 195-199, 2013

[51] Gilbert J. R. B., “Critical assessment, the uses of titanium” Metarials Science and Technology, $1,25,1985$

[52] Rao T. S., Kora A. J., Anupkumar B., Narasimhan S. V., Feser R., "Pitting corrosion of titanium by a freshwater strain of sulphate reducing bacteria (Desulfovibrio vulgaris)" Corrosion Science, 47, 1071-1084, 2005

[53] Flemming H.C., "Biofouling in water systems- cases, causes and countermeasures" Applied microbiology biotechnology, 59, 629-640, 2002

[54] Starosvetsky J., Starosvetsky D., Armon R., "Identification of microbiologically influenced corrosion (MIC) in industrial equipment failures" Engineering failure analysis, 14, 1500-1511, 2007

[55] Borenstein S.W., "Microbiologically influenced corrosion handbook" Woodhead Publishing Limited, 0-8311-3056-3, Cambridge, England, 1994

[56] Sanli Yurudu N.O., "A Short Methodology Review: for the evaluation of biocides against biofilms in recirculating water systems, Microbial pathogens and strategies for combating them: science, technology and education” Edited by Méndez-Vilas A., 3-10, 2013

[57] Videla H.A., "Prevention and control of biocorrosion" International Biodeterioration and Biodegradation, 49, 259-270, 2002 
[58] Guiamet P.S., Gomez De Saravia S.G., "Laboratory studies of biocorrosion control using traditional and environmentally friendly bicides: an overview” Latin American Applied Research, 35, 295-300, 2005

[59] Payne S. J. O. "Interactions of corrosion control and biofilm on lead and copper in premise plumbing" Doctoral thesis Dalhousie University, Halifax, Nova Scotia, 2013

[60] Guezennec, J.G., "Cathodic protection and microbially induced corrosion" International Biodeterioration and Biodegradation, 34, 275-288, 1994

[61] Jayaraman A., Earthman J. C., Wood T. K., "Corrosion inhibition by aerobic biofilms on SAE 1018 steel” Applied Microbiology and Biotechnology, 47, 62-68, 1997

[62] Mansfeld F., "The interaction of bacteria and metal surfaces" Electrochimica Acta, 52, 76707680, 2007

[63] Zuo R., Kus E., Mansfeld F., Wood T.K., "The importance of live biofilms in corrosion protection" Corrosion Science, 47, 279-287, 2005 